\title{
Determination of Brucella. abortus Biovars infected human in the middle and
} southern of iraq

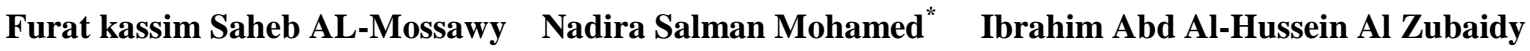 \\ College of Veterinary Medicine / University of Baghdad \\ * Forensic DNA Research and Training Center / Al-Nahrain University
}

E-mail:nadmohamed2000@yahoo.com

\begin{abstract}
Background: Brucella abortus (B. abortus) is a zoonotic bacterium causes both health and economic losses in Iraq.

Objective: The isolation and detection of species and subspecies is very important to understand how the outbreak occurs and to improve vaccine.

Materials and methods: To determine the dominant Biovars (bv) in Iraq (150) blood samples were collected from patients suspected with brucellosis from (Baghdad, Wasit, Babil, Karbala, Al Najaf, AlQadisiyah, Maysan, Al-Muthanna and Al Basrah) hospital's from June 2015 to February 2016. Serum was separated and tested using Rose Bengal Plate Test (RBPT) and Enzyme Linked Immune Sorbent Assay (ELIDA), then positive samples to ELISA were cultivated on Brucella agar. Bacteria were tested to biotyping using both conventional methods include $\left(\mathrm{CO}_{2}\right.$ requirement, urease test, $\mathrm{H}_{2} \mathrm{~S}$ production, and growth on dyes), and Non-conventional methods include AMOS-ERY using set of primers (PIS711, PBa, ERY1, ERY2 and DEL569).

Results: Ninety six samples were found positive and (54) samples were found negative that tested by RBPT. The ELISA specific for $B$. abortus infected human was conducted on the positive RBPT only (38) samples were found positive and (15) samples were found negative and (43) samples were marked undetermined. The result of biochemical showed $B$. abortus bv $(1,3,4,5,6$ and 9) and B. meletensis (bv2) very closed to the AMOS-ERY test results that showed groups of biovars $(1,3,5,6$ and 9).

Conclusion: The Molecular diagnostics have proven its effectiveness in determining the Biovars of these bacteria.
\end{abstract}

Key words: Brucella, conventional PCR, Biovars, Sequence.

\section{Introduction}

Brucellosis is consider as one of the most worldwide distribution zoonotic disease, result from bacteria of the genus Brucella infects cattle, sheep, goats, pigs, and other animals, leading to infertility, abortion, and low milk production [1]. In development countries in which foodborne brucellosis caused by B. abortus or $B$. suis, that made very largely occupational and the majority of situations are males among the ages of 20 and 45 years. Also brucellosis consider as a largely pediatrics problem and these conditions children account for a high proportion of acute cases [2].In the genus Brucella there are ten species described. Host preference for B. melitensis, B. abortus, B. canis, B. ovis, B. suis and B. pinnipedialis are sheep, bovine, dogs, swine, pinnipeds, respectively [3]. B. abortus biovars have special geographic distributions $B$. abortus bv1 and bv 2 are worldwide distributed, while B. abortus bv3 is found predominantly in Egypt, India, Italy, and Africa. B. abortus bv5 is most commonly found in United Kingdom and Germany [4], But has also been observed in France [5].B. abortus bvs. 4 and 6 have been reported in France and Mexico, though less frequently than bv.1, 2, and 3 [6]. B. abortus bv. 4 were also notified in Canada [7], Ecuador, Chile, and Cuba [8]. In India, B. abortus bv1 is the most frequent, followed by $B$. abortus bv3, although bv.4, 6, and 9 were also found [9]. In Iraq, there is no any study to detect B. abortus bvs, so we decided to conduct this study. 


\section{Materials and Methods}

Preparation of human blood Samples

Five $\mathrm{ml}$ of blood was taken from humeral vein by sterile syringe after clean the area was wiped by ethanol $70 \%$ then the blood samples were kept in ethylene Diamine tetra acetic acid (EDTA) tubes and preserved at $\left(4^{\circ} \mathrm{C}\right)$ and transported to the laboratory, then each blood samples were divided into two tube, $2.5 \mathrm{ml}$ centrifuged the samples with $6000 \mathrm{xg}$ for 5 minutes, the serum was obtained and used for RBPT for diagnosis of positive and negative specimens, the other $2.5 \mathrm{ml}$ blood were supplemented to EDTA tube and preserved at $\left(-20^{\circ} \mathrm{C}\right)$ until use for isolation and PCR.

\section{Rose Bengal Plate Test Procedure (RBPT)}

Rose Bengal plate test was done for all samples according to Omega Diagnostics Company (United Kingdom), and procedures mentioned by Office International des Epizooties [10].

\section{Enzyme linked Immune Sorbent Assays (ELISA)}

Serum samples from human were analyzed for the presence of $B$. abortus specific antibodies using indirect ELISA commercial kits following manufacturer's instructions of ID SCREEN® BRUCELLOSIS SERUM INDIRECT MULTI.SPECIES from (IDvet. Germany) [11].

\section{Isolation and Biotyping of bacteria}

About $0.1 \mathrm{ml}$ of heparinized blood was transferred onto each duplicated plate of Brucella agar and spread with a sterile bent glass rod and the plates were placed in atmosphere incubator at $37{ }^{\circ} \mathrm{C}$ and $5.10 \% \mathrm{CO}_{2}$ for isolation of Brucella spp, the presence of Brucella colonies appear after about 5 days, smear from these isolates were made and stained by modified Ziehl-Neelsen's stain,then tested for $\mathrm{CO}_{2}$ requirement, $\mathrm{H}_{2} \mathrm{~S}$ Production, Urease Test, and Growth on Dyes [12].

\section{Molecular Detection of Brucella spp}

Genomic DNA was extracted using Presto ${ }^{\mathrm{TM}}$ Mini gDNA Bacteria Kit, Geneaid Biotech Ltd (USA). Brucella spp were detected using Abortus. Melitensis. Ovis. Suis(AMOS) ERY PCR method [13]. The template DNA, and primers were added to the PreMix iTagTMDNA Polymerase from iNtRON Biotechnology (Canada) in PCR tubes .The first primer mix contained the two primers PIS711 and PBa specific for B. abortus species to amplified fragment sized $498 \mathrm{bp}$. The second primer mix contained three primers the ERY1 and ERY2 primers specific for the eryC-eryD region from B. abortus and DEL569 primer specific for $5.4 \mathrm{~kb}$ fragment deleted in some field strains and bvss of B. abortus to amplify. The oligonucleotides used in this study are listed in Table (1).

\section{Molecular detection of Brucella spp Biovars by PCR Amplification of $f b a$ and Omp2 partial genes}

To detect the B. abortus bvs the PreMix iTagTMDNA Polymerase from iNtRON Biotechnology (Canada) was used in PCR tubes, first primer mix contained the two primers design for the first time in this study Ban $\mathrm{F}$, and Ban R that amplified the fructose bisphosphate aldolase (fba A) partial gene to detect the Brucella species, through amplified fragment sized $551 \mathrm{bp}$. The second primer mix contained primers the Omp2aF and Omp2aR primers specific for the B. abortus bvs to amplified fragment size $1100 \mathrm{bp} \mathrm{kb}$. The third primer mix contained primers the Omp2bF and Omp2bR primers specific for the B. abortus bvs to amplified fragment size $1200 \mathrm{bp}$. The oligonucleotides used in this study are listed in Table (2). Evolutionary analyses were conducted in MEGA6 [14]. The phylogeny was inferred using the UPGMA method [15], and the evolutionary distances were computed using the Maximum Composite Likelihood method [16]. 
Table (1) : AMOS-ERY PCR Primers used to amplify DNA of B. abortus biovars

\begin{tabular}{|l|l|l|l|l|}
\hline Primer & $\begin{array}{l}\text { Amplicons } \\
\text { Size }\end{array}$ & Marker & $\begin{array}{l}\text { Annealing } \\
\text { Temperature }\end{array}$ & References \\
\hline $\begin{array}{l}\text { PIS711F:5'TGCCGATCACTTAAGGGCCTTCAT-3' } \\
\text { PBa R:5'-GACGAACGGAATTTTTCCAATCCC-3' }\end{array}$ & $498 \mathrm{bp}$ & $\begin{array}{l}\text { Brucella } \\
\text { spp. }\end{array}$ & $54.5^{\circ} \mathrm{C}$ & $\begin{array}{l}\text { Bricker, } \\
2002\end{array}$ \\
\hline $\begin{array}{l}\text { ERY1:5'-CGCCTGCGTGACCTCCAGCTTACCC-3' } \\
\text { ERY2:5'-GGCCATGACACGCGGCATATAACC-3' } \\
\text { DEL569:5'-GCGCAGCGTTGCGGCAATTG-3' }\end{array}$ & $\begin{array}{l}\text { eryC-eryD } \\
\text { region127- } \\
\text { bp1700 bp }\end{array}$ & $\begin{array}{l}\text { B. abortus } \\
\text { bvs }\end{array}$ & $58^{\circ} \mathrm{C}$ & $\begin{array}{l}\text { OcampoS } \\
\text { osa et } \\
\text { al.,2005 }\end{array}$ \\
\hline
\end{tabular}

Table (2) : Primers used to amplify DNA of Brucella.spp of fba and omp2 genes

\begin{tabular}{|l|l|l|l|l|}
\hline \multicolumn{1}{|c|}{ primers } & $\begin{array}{l}\text { Amplicons } \\
\text { Size }\end{array}$ & Marker & $\begin{array}{l}\text { Annealing } \\
\text { Temperature }\end{array}$ & References \\
\hline $\begin{array}{l}\text { Ban/F:5'-ATCCGATTGCTTTCCTCGCC-3' } \\
\text { Ban/R:5'-GTTATAGTCCCAGTCGGCGG-3' }\end{array}$ & $\begin{array}{l}551 b p \\
F b a\end{array}$ & $\begin{array}{l}\text { Brucella } \\
\text { spp }\end{array}$ & $60^{\circ} \mathrm{C}$ & $\begin{array}{l}\text { In this } \\
\text { study }\end{array}$ \\
\hline $\begin{array}{l}\text { Omp2a/F:5'GGCTATTCAAAATTCTGGCG-3' } \\
\text { Omp2a/R:5'-ATCGATTCTCACGCTTTCGT-3' }\end{array}$ & $\begin{array}{l}1100 \text { bp } \\
\text { Omp2a }\end{array}$ & B.abortus & $62^{\circ} \mathrm{C}$ & [17] \\
\hline $\begin{array}{l}\text { Omp2b/F:5'-CCTTCAGCCAAATCAGAATG-3' } \\
\text { Omp2b/R:5'-GGTCAGCATAAAAAGCAAGC-3' }\end{array}$ & $\begin{array}{l}1200 \text { bp } \\
\text { Omp2b }\end{array}$ & B.abortus & $56^{\circ} \mathrm{C}$ & $(17]$ \\
\hline
\end{tabular}

\section{Results}

Out of (150) serum samples examined, 96/150 (64\%) were positive to RBPT and 54/150 (36\%) are negative to RBPT. That positive (96) RBPT samples were submitted to ELISA assays .The results indicated that $38 / 96(39.5 \%)$ serum samples were positive to ELISA, 43/96 (44.8\%) samples were negative, and $15 / 96$ (15.62) were suspected. Bacterial isolation and identification by conventional methods indicated 4 isolates belong to $B$. abortus and one to B .melitensis with typical characterization: the growth of small, round, glistening, smooth or sometimes mucoid colonies on Brucella agar plates at 3-5 days post incubation at $37^{\circ} \mathrm{C}$, while on blood agar appeared non-hemolytic with round, convex, smooth margin, translucent, honey-colored, glistening, and bluish. Biotyping result was showed on the Table (3).

Table (3) : Conventional biochemical results of Brucella. spp detection

\begin{tabular}{|c|c|c|c|c|c|c|}
\hline $\begin{array}{c}\text { Brucella } \\
\text { Isolates }\end{array}$ & $\begin{array}{c}\text { Requirement } \\
\text { of } \mathbf{1 0 \%} \mathbf{C O}_{\mathbf{2}}\end{array}$ & $\begin{array}{c}\text { Production } \\
\text { of } \mathbf{H}_{\mathbf{2}} \mathbf{S}\end{array}$ & $\begin{array}{c}\text { Growth } \\
\text { on } \\
\text { Thionin }\end{array}$ & $\begin{array}{c}\text { Growth } \\
\text { on Basic } \\
\text { Fuschin }\end{array}$ & Urease & Results \\
\hline 2 & $(+/-) \mathrm{a}$ & + & - & + & $+>1 \mathrm{hr}$ & B. abortus bv $(1,4,9)$ \\
\hline 1 & $(+/-) \mathrm{a}$ & + & + & + & $+>1 \mathrm{hr}$ & B. abortus bv3 \\
\hline 1 & $(+/-) \mathrm{a}$ & - & - & + & $+>1 \mathrm{hr}$ & B. abortus bv $(5,6)$ \\
\hline 1 & - & - & + & + & $(+<30)$ & B. melitensis bv2 \\
\hline
\end{tabular}

a. positive is dominant characteristic, but negative strain occur.

\section{Molecular Detection Results}

Extracted DNA concentration of was ranged between 50-100 ng / $\mu \mathrm{l}$ and the purity ranged between $1.8-$ 1.9. Gene fragments was amplified by Enhanced AMOS.ERY PCR method from DNA of all 5 Brucella field strains, our finding confirmed that all 5 isolates were belong to Brucella strains showed in Figure (1) and mentioned in band that sized $1270 \mathrm{bp}$ in lanes $1,2,3$, and 4 . Isolates were belonged to B. abortus bv $3 \mathrm{~b}$, 
5, 6, 9 mentioned in band that sized 1700 bp in both lanes 1,3 , and 4 .When one isolate belong to $B$. abortus bv1detected in lanes 1 with band sized $498 \mathrm{bp}$.

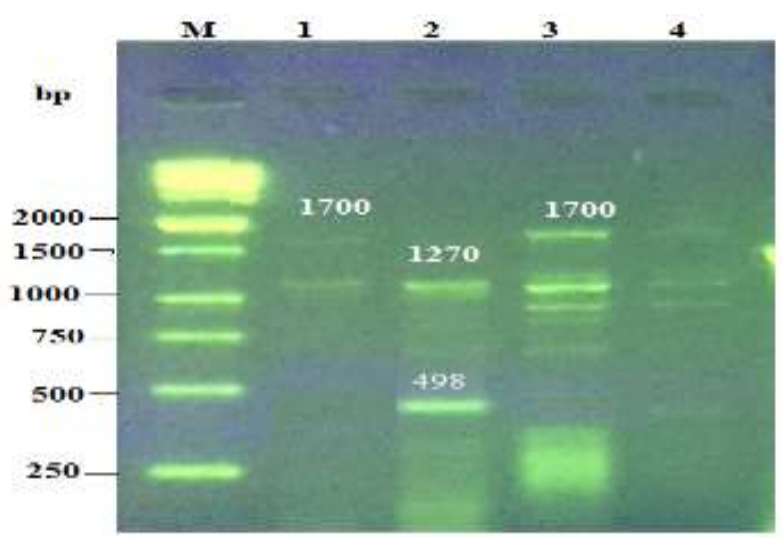

Figure (1): The gel electrophoresis results of Enhanced AMOS.ERY PCR. M. DNA Marker 250-10000 bp, Lane 1, 3, and 4 B. abortus bv 3, 5, 6, and 9 bands profile, Lane 1. B. abortus bv 1. Using $2 \%$ Agarose stained with red safe DNA dye and electrophoresed by $5 \mathrm{vol} / \mathrm{cm}$ in TBA buffer

\section{PCR Amplification and gene sequence results}

In the current study, the amplicons of fpa A flanking region that showed in Figure (2). The amplification of the porin gene included the flanking region of porin 2 outer membrane protein gene (Omp2a; Omp2b) partial gene sized $1100 \mathrm{bp}$ and $1200 \mathrm{bp}$ respectively as mentioned in the Figure (3) and Figure (4). The genetic sequencing analysis of fbaA PCR product of B. abortus Iraqi isolates were $100 \%$ identical with

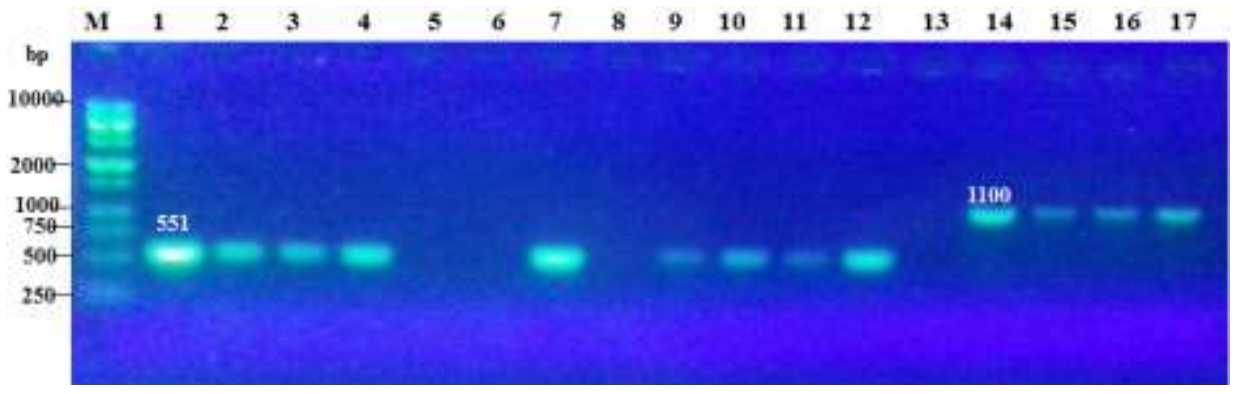

Figure (2): The gel electrophoresis results of $f b a \mathrm{~A}$, and Omp2a partial gene using $1.5 \%$ Agarose stained with red safe DNA dye and electrophoresed by $5 \mathrm{vol} / \mathrm{cm}$ in TBA buffer. Lane M indicate DNA

Marker 250.10000 bp, Lane 1,2,3,4,7,9,10,11, and12 fba A551bp partial gene bands and lane $14,15,16,17$ the Omp2a 1100 bp partial gene bands

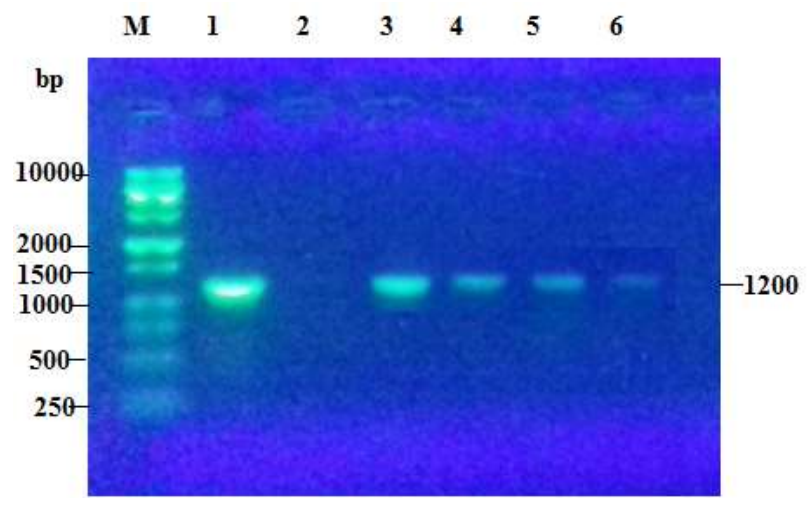

Figure (3): The gel electrophoresis results of 1200 bp Omp2b partial gene band using $1.5 \%$ Agarose stained with red safe DNA dye and electrophoresed by $5 \mathrm{vol} / \mathrm{cm}$ in TBA buffer. lane M indicate DNA Marker 250.10000 bp, Lane 1,3,4,5, and 6 Omp2b 1200 bp partial gene band 
(high 990 score and 0.0 E.Value) blasted with fbaA partial sequence of the standard strain B. abortus gb|CP007737.1|, gb|CP007706.1|,and gb|CP007710.1|USA isolates, and 99\% identical with (high 984 score and 0.0 E.Value) partial $f b a A$ gene of B. melitensis, B. suis, B. ovis , B. pinnipedielis from Iraq, USA, and France respectively from different clinical samples. According to the single nucleotide polymorphism and nucleotide substitution A/G 301534 nt in object sequence gb|CP007710.1| and 353 in query sequence and the translated protein the substitution in the amino acid Cytosine(A) changed to Thymine(T) as marked with black raw in Figure( 5) and Figure(6). The phylogeny branch length $=0.00203245$ is shown in Figure (7). The analysis involved 11 nucleotide sequences. There were a total of 494 positions in the final dataset.

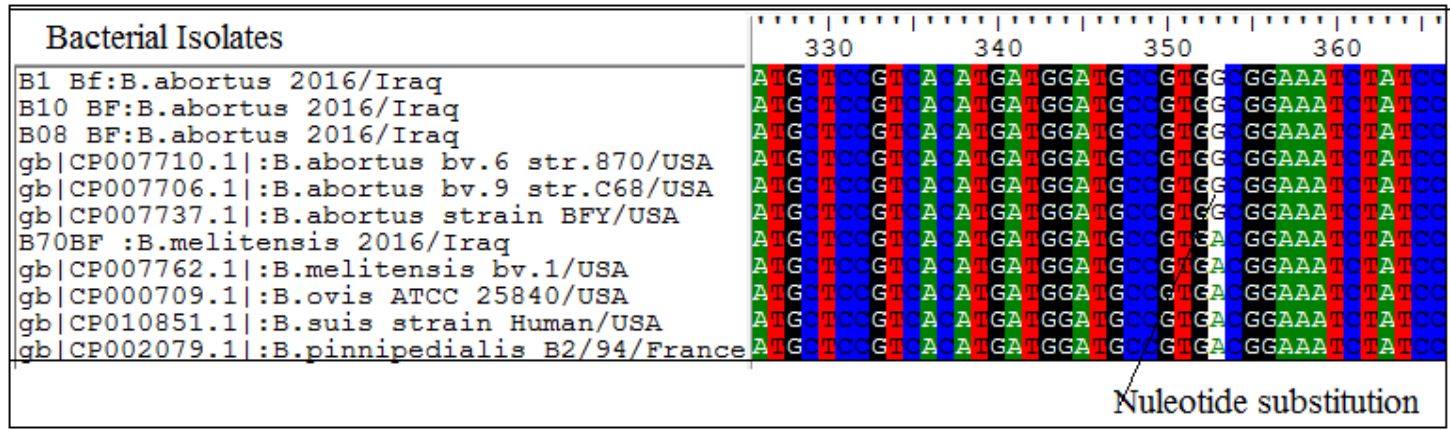

Figure (4): Nucleotide sequence of sense flanking the partial $\mathrm{fba} A$ gene compared with the related identity to gene bank strains of B. melitensis, B. ovis, B.suis fba A gene using the BioEdit program

\begin{tabular}{|c|c|}
\hline Bacterial Isolates & 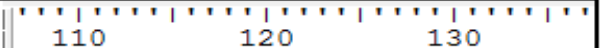 \\
\hline 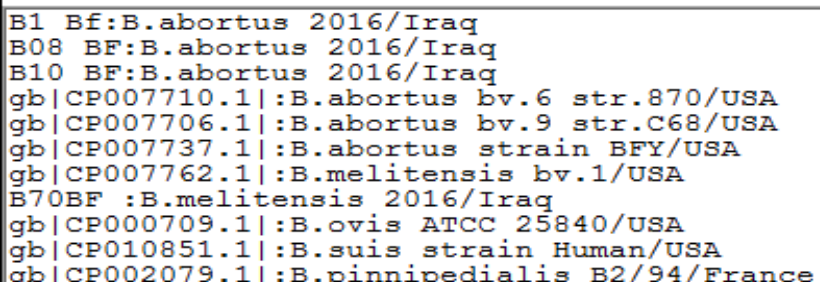 & 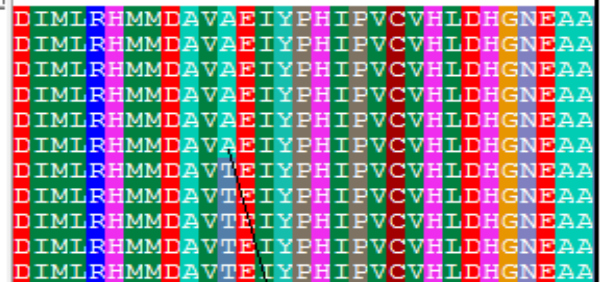 \\
\hline
\end{tabular}

Figure(5): Translated Sequence of sense flanking the partial $\mathrm{fbaA}$ gene compared with the related identity to gene bank strains of B. melitensis, B.ovis, B.suis, fbaA gene using the BioEdit program

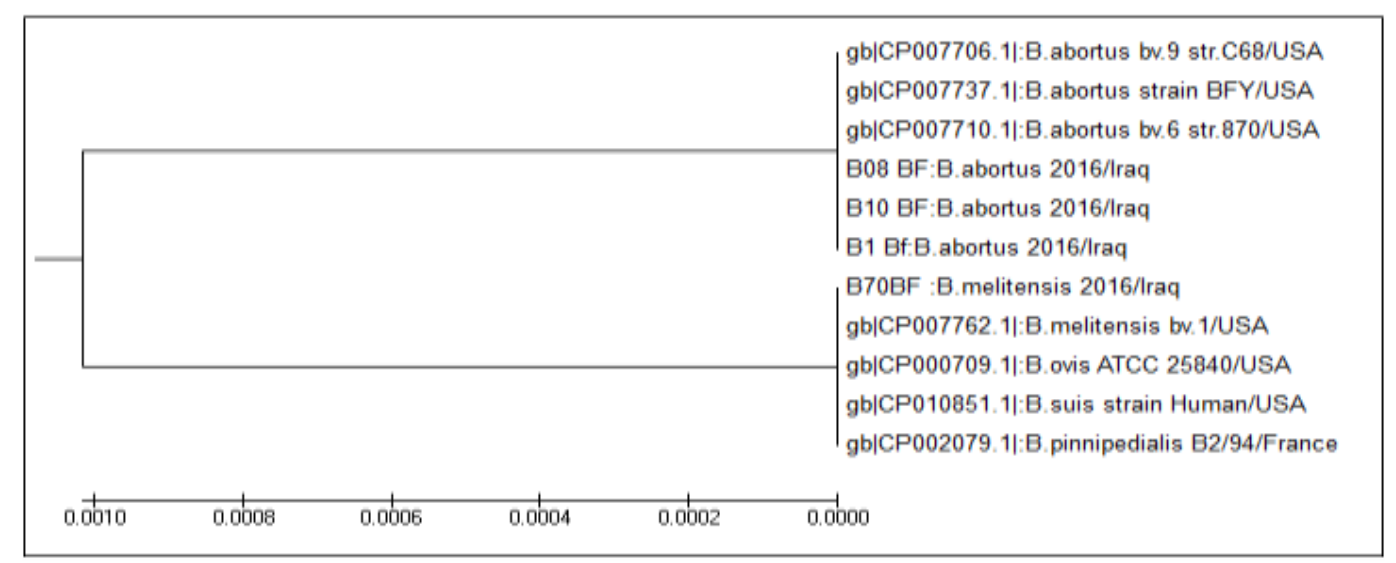

Figure (6): The phylogenetic tree of sense flanking the partial ( $f b a \mathrm{~A}$ ) gene in $\mathrm{B}$. abortus bacteria isolated in Iraq during 2015.2016 in compared with the related identity to gene bank strains of $B$. melitensis, B. ovis, B. suis, B. pinnibedialis $(f b a A)$ gene. The B. abortus bv. 9 str. C68 gb|CP007706.1| was used as the root for the tree 
The genetic sequencing analysis of porin gene of omp $2 a$ flanked region PCR product of B. abortus Iraqi isolates $\mathrm{B} 08 \mathrm{BF}$ and $\mathrm{B} 1 \mathrm{BF}$ were $100 \%$ identical with the standard strain B. abortus gb|CP007737.1|, $\mathrm{gb} \mid \mathrm{CP} 007706.1$,and $\mathrm{gb}|\mathrm{CP} 007710.1| \mathrm{USA}$ isolates, and with $99 \%$ identical and with $99 \%, 99 \%$, and $98 \%$ of blasted strains gb|259048725.1|, gb|AE017223.1| , and gb|CP007765.1| respectively were showed in Figure (7). The B. abortus bv. 9 str. C68 gb|CP007706.1| was used as the root for the tree is drawn to scale, with two main branches, lengths in the same units as those of the evolutionary distances used to infer the phylogenetic tree. The analysis involved 8 nucleotide sequences. There were a total of 740 positions in the final data set. Figure (8). Is showen the evolutionary relationships of taxa Omp2b. The optimal tree with the sum of branch length $=13.57527083$ is shown.

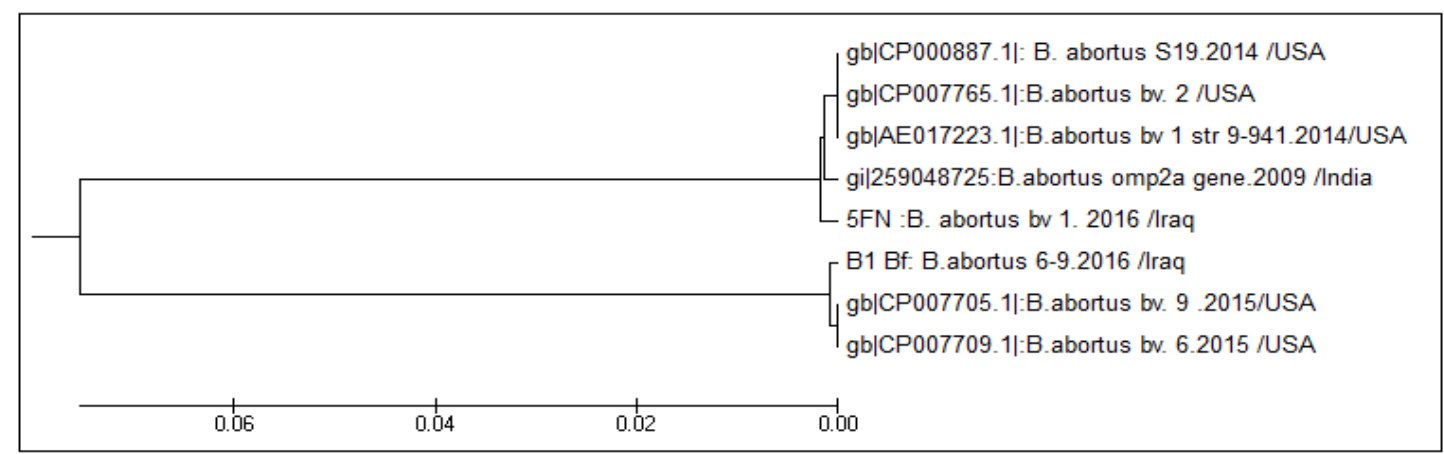

Figure (7): The phylogenetic tree of partial Omp2a gene sequence in compared with highly related identity to gene bank strains gene in $B$. abortus bacteria isolated in Iraq during 2015.2016 in compared with the related identity to gene bank strains. The $B$. abortus bv. 9 str. $\mathrm{C68}$ gb|CP007706.1| was used as the root for the tree

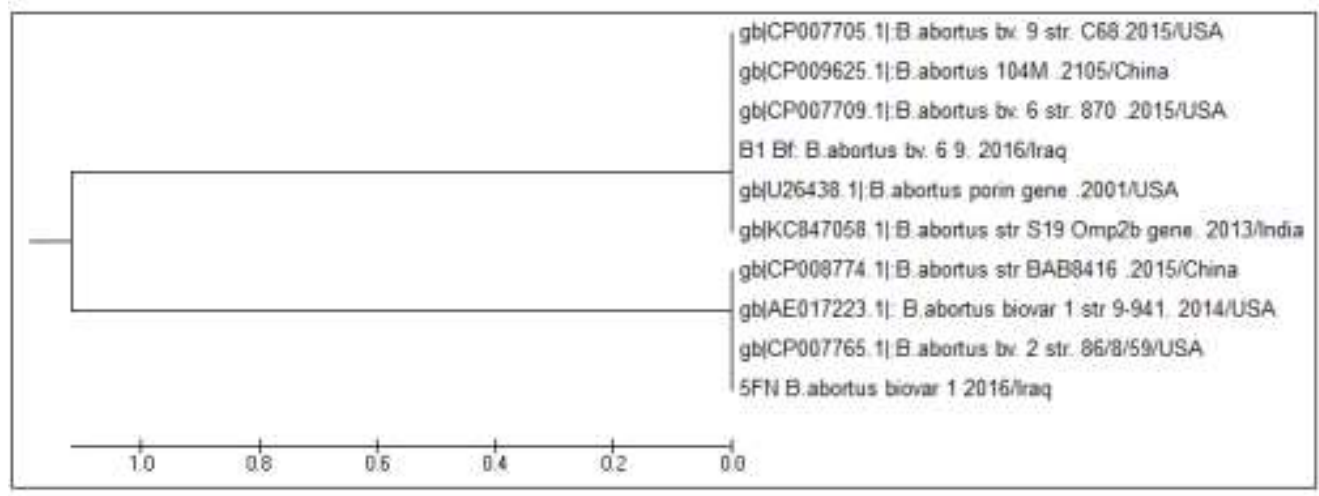

Figure (8): The phylogenetic tree of partial Omp2b gene sequence in compared with highly related identity to gene bank strains gene in $B$. abortus bacteria isolated in Iraq during 2015.2016 in compared with the related identity to gene bank strains. The $B$. abortus bv. 9 str. C68 gb|CP007706.1| was used as the root for the tree

There were a total of 855 positions in the final dataset. The upper branch included the B1Bf Iraqi isolate suspected B. abortus bv 6 or 9 located on the same distance with B. abotrus gb|CP007705.1|, gb|CP007709.1, gb|CP008774.1| ,gb|CP009625.1|were 100\% identical with (high 2012, 2018, 2008, 2384 score and 0.0 E.Value) respectively, and B. abortus. On the other hand the lower branch included 5FN Iraq isolate suspected B. abortus bv was blasted $100 \%$ identical with B. abortus bvs 1 str 9941 /USA gb|AE017223.1| (high 2390 score and 0.0 E.Value) located on the same distance with the other related strain of B. abortus, gb|CP007765.1|, gb|U26438.1| with 99\% identical. These finding indicated that the B1Bf Iraqi isolates is belong to the B. abortus bv 9 and the 5FN Iraq isolate is belong to the B. abortus bv 1 . 


\section{Discussion}

The agreement between ELISA test and RBPT showed low ratio. Both RBT and ELISA are Office international des epizooties (OIE) prescribed screening tests for brucellosis. In the present study, RBPT and IELISA tests showed wide differences in their sensitivity, this agree with many researchers who explain that the sensitivity of RBPT was much lower than ELISA test because of Rose Bengal plate test is an agglutination test that is based on reactivity of antibodies against smooth lipopolysaccharide(LPS). The ELISA test have ability to indicate the lowest concentration of exact antibody and this cannot be detected in case of RBPT and explain the lower number of positive cases in ELISA than RBPT [11] . The result of the growth on Brucella agar plates shows bacterial characteristics that agree with that mentioned by [10].The number of our isolates was lack because Brucella is intracellular and the number of circulating bacteria is usually low. Removal/dilution of antibacterial substances, concentration of bacteria and optimal culture conditions may enhance the rate of isolation [18]. The biotyping results showed that the growth of Brucella that require $\mathrm{CO}_{2}$, which indicate to Brucella abortus, while Brucella that don't require $\mathrm{CO}_{2}$ it is Brucella melitensis and some $B$. abortus strain don't required $\mathrm{CO}_{2}$ this result agree with [10], they record some of $B$. abortus strains that did not require $\mathrm{CO}_{2}$, these considered to be biovar 5, 6, 9. Growth of Brucella that produced $\mathrm{H}_{2} \mathrm{~S}$, indicate $B$. abortus while Brucella that don't produce $\mathrm{H}_{2} \mathrm{~S}$ is $B$. melitensis do not produced it [19]. This result was in agreement with USA National Veterinary Services Laboratory and OIE with exception that some strains of Brucella abortus that isolate in our study don't produce $\mathrm{H}_{2} \mathrm{~S}$ and they mentioned that these biovars may represent biovar 5, 6. One isolate produce pink color in a period longer than one hour this indicate B. abortus and B. melitensis biovars other than biovar 2 [20] this result was also in agreement with [10]. The other isolates give pink color in a period less than 30 minute and they all refers to be $B$. melitensis biovar 2. The isolate grew on thionin and basic fuchsin dyes. These isolate that grow in existence of the two dyes may indicate $B$. abortus biovar 3 and $B$. melitensis (bv 1,2,3). In this study many isolates grew on basic fochcin only, these may indicate all $B$. abortus biovars except bv. 2. Several isolate did not grow on basic fuchsin and thionin, these may indicate the presence of B. abortus (bv 2). These results agree with [10,12].

\section{Molecular detection of Brucella bvs.}

The highly similarity among Brucella biovars and the unstablity of some phenotyping characters makes it difficult to obtain some biovars. In the recent time, the molecular methods became more reliable techniques for the genotyping of Brucella strains. Biotyping provides valuable epidemiological information that allows tracing of infections back to their sources in countries where several biotypes are co-circulating. However, when one particular bv is over whelming predominant, classical typing techniques are of no use because they do not allow the differentiation of isolates belonging to the same bv for a given biotype [21].We have used AMOS. ERY PCR primer cocktail, which produced a PCR fragment of $1270 \mathrm{bp}$ from all the Brucella strain, and 1700 bp only from the isolates of bvs 3b, 5, 6 and 9 of $B$. abortus and band sized 498 bp indicated B. abortus bv1. But not from other species and biovars of Brucella revealed the existence of a $5.4 \mathrm{~kb}$ deletion close to an IS711 Copy and as mentioned by Bricker, and Ocampo [22]. The B. abortus was detected according to the SNP and nucleotide substitution A/G 301534 nt in object sequence $\mathrm{gb}|\mathrm{CP} 007710 . \quad 1|$ and 353 in query sequence and substitution in the amino acid Cytosine changed to Thymine. All B. abortus isolates were have the Glycine amino acid instead of Alanine which present in the other species such as B. melitensis, B. ovis, B. suis. The phylogenetic tree of sense flanking the partial fructose bisphosphate aldolase $(f b a \mathrm{~A})$ gene used $B . \quad$ abortus bv. 9 str. $\quad$ C68 gb|CP007706. 1| as the root for the tree in showed two branches length $=0.00203245$, the upper one including one clad length 0.0010 the first clad leafs contain all $B$. abortus bvs and the second clad contain the $B$. melitensis, $B$. ovis, $B$. pinnibedialis $B$. suis. $F b a$ gene represents one position of nucleotide substitution. As we note that, the SNP in the $f b a \mathrm{~A}$ gene is very suitable to differentiate the $B$. abortus species from the other Brucella species and this agreement with Gopaul et al., [21] and Kim et al. ,[22]. In the other hand we used Omp2a and Omp2b to display characteristics host rang following Ficht et al., [23], whom suggested that the major outer membrane protein contain taxonomically relevant information. According to these results, we reported Brucella abortus biovars 1, 3, 6 and 9 for the first time in Iraq. We found that the B. abortus bv. 1 is the most dominant biovars and this consistence with the other finding of , [24 , 25], and with [19] whom mentioned that bv1 is worldwide distribution . 
In our study, the high isolation frequency of B. abortus bv. 1 and bv. 3 could be explained by the continuous importation of cattle and buffalos between Iraqi provinces as mentioned by, and because that the origin of most cattle and buffalos imported into Iraq were came from Europe and India. Indian studies referd to that $B$. abortus bvs. 6, 9 were most frequent bvs. of B. abortus in cattle and buffalos in India [9, 26]. The Iraqi $B$. abortus isolates were more distantly related to USA, China, France and India isolates, Brucella isolates sequences that better understanding of the epidemiology and control of bovine brucellosis in the region as we noted the limited amount of sequence data available on the NCBI about $B$. abortus because the working on this species started late, and more data will be available in future. The PCR technique most preferd method to diagnosis B. abortus lead to control and eradication of brucellosis in cattle and buffalos and decrease economic losses O'leary et al., [27].This study allows comparing the biovars of B. abortus in Iraq with those neighbors' countries. Our study diagnose Biovars $(1,3,6,9)$ to be exists in Iraq, these biovars when previously diagnose in Iran, Turkey, Kuwait, Saudia Arabia and Syria. The uncontrolls movement of animal's through border areas represent the most acceptable reason to their existing in Iraq.

\section{Conclusion}

Through the study we conclude that conventional biochemical results of $B$. abortus bv are $(1,3,4,5,6$ and 9) and B. meletensis (bv2) very closed to the AMOS-ERY test results that of biovars (1, 3, 5, 6 and 9). The Molecular diagnostics have proven its effectiveness in determining the biovars of these bacteria.

\section{References}

1. Yasmin B, Lone SA. Brucellosis: An Economically Important Infection. J. Med Microb Diagn.(2015);4: 208.

2. Lopes L, Nicolino R, Hadad J .Brucellosis- risk factors and prevalence: a review. Open Vet.Sci.J. (2010); 4:72-84.

3. Silva J, França S, Paixão T, Santos R. Laboratorial diagnosis of animal brucellosis(2014); 10.4322/rbcv.106.

4. Hirsh DC, Zee YC. Microbiologia Veterinária. Rio de Janeiro: Guanabara Koogan.( 2003); 191-195.

5. Garin-Bastuji B, Letesson J J. From the discovery of the Malta fever's agent to the discovery of a marine mammal reservoir, brucellosis has continuously been a reemerging zoonosis. Vet. Res. (2005);36:313-326.

6. Luna-Martínez JE, Mejía-Terán C. Brucellosis in Mexico: current status and trends. Vet Microbiol. (2002); 90: 19-30.

7. Ragan V. The Animal and Plant Health Inspection Service (APHIS) Brucellosis eradication program in the Unites States. Vet Microbiol. (2002); 90:11-18.

8. Geresu MA, Kassa GM .A Review on Diagnostic Methods of Brucellosis.J. Veterinar Sci Techno. (2016); 7:323.

9. Renukaradhya G, Isloor S, Rajasekhar M. Epidemiology, zoonotic aspects, vaccination and control/eradication of brucellosis in India. Vet. Microbiol (2002); 90, 183-10. O.I.E. Ovine Brucella ovies In: Mannual of diagnosis test and vaccines for terrestrial animals. Paris: Office international des epizooties (2009); 1-9.195.

11. Mathew C, Stokstad M, Johansen T B, Klevar S, Mdegela RH, Mwamengele G, Michel P, Escobar L, Fretin D , Godfroid J. First isolation, identification, -phenotypic and genotypic characterization of B. abortus biovar 3 from dairy cattle in Tanzania.Mathew et al. BMC Veterinary Research.(2016);11(156):0476-8.

12. Quinn PJ, Carter ME, Markey B, carter GR . Clinical Veterinary Microbiology. Mobsy International Limited, Edinburgh. (2007); 261-267. 
13.Vercesi AE, Carvalho FG, Madalena FE. Estrura populacional do rebanho indubrasil registrado no Brasil. Arch Latinoam Prod Anim. (2000);10:86-92.

14. Tamura K, Stecher G, Peterson D, Filipski A, Kumar S. MEGA6: Molecular Evolutionary Genetics Analysis version 6.0. Molecular Biology and Evolution. (2013);30: 2725-2729.

15. Sneath PHA, Sokal RR. Numerical Taxonomy. Freeman, San Francisco (1973).

16. Tamura K, Nei M, Kumar S. Prospects for inferring very large phylogenies by using the neighborjoining method. Proceedings of the National Academy of Sciences (USA). (2004); 101:11030-11035.

17. Cloeckaert A, Verger JM, Grayon MO. Restriction site polymorphism of the genes encoding the major $25 \mathrm{kDa}$ and $36 \mathrm{kDa}$ outer-membrane proteins of Brucella. Microbiol.(1995); 141:2111-2121.

18. Mangalgi M, Sajjan A. Comparison of Three Blood Culture Techniques in the Diagnosis of Human Brucellosis. J. Lab Physicians.(2014); 6(1): 14-17.

19. Schurig GG, Roop RM, Bagchi T, Boyle S, Buhrman D, Sriranganathan N. Biological properties of RB51; a stable rough strain of Brucella abortus. Vet Microbiol .(1991); 28(2):171-88.

20. Markey BK, Leonard FC, Cullinane A, Archambault M, Maguire D. Clinical veterinary microbiology bovina: uma atualização. Revista Brasileira de Reprodução Anim. (2013); 32:202-212.

21. Godfroid J, Scholz HC, Barbier T, Nicolas C, Wattiau P, Fretin D. Brucellosis at the animal/ecosystem/human interface at the beginning of the 21st century. Prev Vet Med . (2011); 102:118-31.

22. Bricker BJ. PCR as a diagnostic tool for brucellosis. Vet Microbiol. (2002); 90, 435-446.

23. Gopaul KK, Koylass MS, Smith CJ Whatmore AM. Rapid identification of Brucella isolates to the species level by real time PCR based single nucleotide polymorphism (SNP) analysis. BMC Microbiol. (2008); 8: 86.

24. Kim Ji-Yeon, Kang S, Lee J, Lee K, Sung S, Jung S, Park Y, Yoo H. Her Differential Diagnosis of Brucella abortus by Real-Time PCR based on a Single-Nucleotide Polymorphisms, Clin Microbiol. (2015); 4:5.

25. Ficht TA, Husseinen HS, Derr J, Bearden SW. Species-specific sequences at the omp2 locus of Brucella type strains. Int.J. Syst. Bacteriol. (1996); 46, 329-331.

26. Poester FP, Goncalves VSP, Lage AP. Brucellosis in Brazil. Vet. Microbiol. (2002); 90,55-62.

27. O’Leary S, Sheahan M, Sweeney T. Brucella abortus detection by PCR assay in blood, milk and lymph tissue of serologically positive cows. Res Vet Sci. (2006); 81: 170-176. 